\title{
Polio Across the Iron Curtain
}

By the end of the 1950s Hungary became an unlikely leader in what we now call global health. Only three years after Soviet tanks crushed the revolution of 1956, Hungary became one of the first countries to introduce the Sabin vaccine into its national vaccination programme. This immunisation campaign was built on years of scientific collaboration between East and West, in which scientists, specimens, vaccines and iron lungs crossed over the Iron Curtain. Dóra Vargha uses a series of polio epidemics in communist Hungary to understand the response to a global public health emergency in the midst of the Cold War. She argues that despite the antagonistic international atmosphere of the 1950s, spaces of transnational cooperation between blocs emerged to tackle a common health crisis. At the same time, she shows that epidemic concepts and policies were influenced by the very Cold War rhetoric that medical and political cooperation transcended. Also available as Open Access.

DÓRA VARGHA is Lecturer in Medical Humanities at the University of Exeter. Her research has been awarded the J. Worth Estes Prize by the American Association for the History of Medicine, and the Young Scholar Book Prize by the International Committee for the History of Technology. 
Global Health Histories

Series editor:

Sanjoy Bhattacharya, University of York

Global Health Histories aims to publish outstanding and innovative scholarship on the history of public health, medicine and science worldwide. By studying the many ways in which the impact of ideas of health and well-being on society were measured and described in different global, international, regional, national and local contexts, books in the series reconceptualise the nature of empire, the nation state, extra-state actors and different forms of globalisation. The series showcases new approaches to writing about the connected histories of health and medicine, humanitarianism, and global economic and social development 


\section{Polio Across the Iron Curtain}

Hungary's Cold War with an Epidemic

Dóra Vargha

University of Exeter 


\section{CAMBRIDGE \\ UNIVERSITY PRESS}

University Printing House, Cambridge CB2 8BS, United Kingdom

One Liberty Plaza, 20th Floor, New York, NY 10006, USA

477 Williamstown Road, Port Melbourne, VIC 3207, Australia

314-321, 3rd Floor, Plot 3, Splendor Forum, Jasola District Centre, New Delhi - 110025, India

79 Anson Road, \#06-04/06, Singapore 079906

Cambridge University Press is part of the University of Cambridge.

It furthers the University's mission by disseminating knowledge in the pursuit of education, learning, and research at the highest international levels of excellence.

www.cambridge.org

Information on this title: www.cambridge.org/9781108420846

DOI: $10.1017 / 9781108355421$

(C) Dóra Vargha 2018

This work is in copyright. It is subject to statutory exceptions and to the provisions of relevant licensing agreements; with the exception of the Creative Commons version the link for which is provided below, no reproduction of any part of this work may take place without the written permission of Cambridge University Press.

An online version of this work is published at doi.org/10.1017/9781108355421 under a Creative Commons Open Access license CC-BY-NC-ND 4.0 which permits re-use, distribution and reproduction in any medium for non-commercial purposes providing appropriate credit to the original work is given. You may not distribute derivative works without permission. To view a copy of this license, visit https://creativecommons.org/licenses/by-nc-nd/4.0

All versions of this work may contain content reproduced under license from third parties. Permission to reproduce this third-party content must be obtained from these third-parties directly.

When citing this work, please include a reference to the DOI 10.1017/9781108355421

First published 2018

Printed and bound in Great Britain by Clays Ltd, Elcograf S.p.A.

A catalogue record for this publication is available from the British Library

Library of Congress Cataloging-in-Publication Data

Names: Vargha, Dóra, 1979- author.

Title: Polio across the Iron Curtain : Hungary's Cold War with an epidemic / Dóra Vargha.

Description: Cambridge ; New York, NY : Cambridge University Press, 2018. I

Series: Global health histories I Includes bibliographical references.

Identifiers: LCCN 2018026566 I ISBN 9781108420846 (hardback : alk. paper) | ISBN 9781108431019 (pbk. : alk. paper)

Subjects: LCSH: Poliomyelitis-Hungary-History. I Poliomyelitis vaccine,

Oral-History. I World health-History-20th century.

Classification: LCC RC181.H9 V37 2018 I DDC 616.8/35009439-dc23

LC record available at https://lccn.loc.gov/2018026566

ISBN 978-1-108-42084-6 Hardback

Cambridge University Press has no responsibility for the persistence or accuracy of URLs for external or third-party internet websites referred to in this publication and does not guarantee that any content on such websites is, or will remain, accurate or appropriate. 